\title{
Reseña sobre LasLulú. Complejidades pedagógicas del cómic
}

\author{
María Celia Costa
}

Con motivo de las II Jornadas de Cómics Expandido y Emergente que se llevaron a cabo en septiembre de 2015 en FADUUNL, el artículo reflexiona acerca de las complejidades pedagógicas del cómic implicadas en nuestro tiempo, desde una perspectiva crítico-política.

En la sociedad posindustrial, en la comunidad administrada, la cultura del consumo de la imagen modifica las formas tradicionales de la transmisión y las posibilidades formativas del arte. Sin embargo, existen lenguajes alternativos, y entre ellos algunas expresiones del cómic, que nos interpelan con agudeza y potencian las capacidades subjetivas, proponiéndonos nuevas perspectivas.

\section{Espacios para pensar, crear y compartir...}

Durante los días 25 y 26 de septiembre de 20I5, en la FADU-UnLse realizaron las II Jornadas de Cómics Expandido y Emergente, organizadas por las cátedras de Motions Cómics y de Medios Expresivos Audiovisuales I y II de la Licenciatura en Diseño de la Comunicación Visual, junto a las Secretarías de Extensión, Académica y de Investigación de la FADU y al grupo TETE, con la coordinación general de la Lic. Ysabel Tamayo y del DGVC Rodrigo Goldsack.

El encuentro formó parte del proyecto de investigación CAI+D $20 I I$ «Narrativas pedagógicas hipermediales para la enseñanza superior: nuevas tecnologías», dirigido por 
Tamayo, con una metodología abierta, rizomática, que estimula la creatividad y la experimentación tanto en los desarrollos teóricos como en los trabajos de campo.

Estas Jornadas nos convocan a pensar, desde la Pedagogía, sobre las complejidades educativas implicadas en nuestro tiempo, tiempo signado en palabras de Régis Debray por la imagen. Y en particular, en la función del cómic como disparador de pensamiento y emociones.

La sociedad posindustrial, el capitalismo global, la posmodernidad, nos instalan en la condición de consumidores de imágenes. La comunicación mediada por pantallas sustituye a la palabra escrita, e incluso modifica los códigos comunicacionales intersubjetivos: selfies, mails, sms, whatsapp, circulan como un nuevo «estar en el mundo".

Ya por la década de 1950, la Escuela de Frankfurt denunciaba los riesgos de la sociedad totalizadora, y frente al fenómeno mundial derivado de la evolución del capitalismo y del repliegue de la política ante las imposiciones de los mercados, la comunidad intelectual tomó posiciones.

En 1964 Umberto Eco publica Apocalipticos e integrados, con una actitud realista y analítica. Si bien Eco declaró luego que no volvería a escribir ese libro del mismo modo, porque él mismo se había convertido en una especie de apocalíptico integrado, la lucidez con que nos advierte que en la cultura de masas los contenidos televisivos y las estructuras narrativas de las revistas y tebeos no hacen más que reforzar las relaciones entre retórica e ideología, consolidando las valoraciones dominantes, aún nos interpela.

Por aquellos mismos años, las posturas críticas neomarxistas de los franceses Althusser, Foucault, Bourdieu, Maud Mannoni, entre otros, nos señalan la condición de la escuela como aparato reproductor de las desigualdades sociales, y como medio de control de los cuerpos y de las conductas, así como de las relaciones de poder que subyacen en la posesión y dosificación del conocimiento.

En Inglaterra, Basil Bernstein, tras años de trabajos de campo, distingue a los niños en dos grupos en relación con los códigos elaborados o restringidos de su lenguaje, que tienen un correlato directo con el origen social de procedencia, según la pertenencia de éstos a la burguesía o a la clase obrera. Frente al hecho, la escuela no hace más que reproducir la desigualdad originaria. Su discípulo Michael Apple, en los Estados Unidos, funda sus desarrollos teóricos actuales en esta tesis.

Las referencias que tomamos para conceptualizar nos inducen a pensar en los procesos clásicos de la transmisión cultural, sustentados básicamente en la palabra, cuya forma masiva ha sido el libro: la palabra escrita. Sin embargo, en las últimas décadas el mercado de la tecnología ha hecho su aparición con una fuerza y una velocidad tan inusitada, que ha modificado sin posibilidades de retorno toda la circulación de 
los saberes, los procesos de comprensión, las pautas de comunicación social y hasta las percepciones y sensibilidad que somos capaces de producir como grupo humano.

Esta revolución tecnológica terminó de jaquear a la institución escolar, con sus escasas posibilidades estructurales y didácticas, asentada todavía en el ideal moderno de igualdad y en la tradición humanista de la palabra oral y escrita.

En la sociedad de masas, en la sociedad administrada, la palabra se ha trasladado a la imagen. Los trámites que hoy nos reclama el ejercicio cotidiano de ciudadanía ya no requieren del formulario escrito, porque su gestión y control es virtual y se aborda por opciones informáticas, gestos (touch), scanners que registran rostros, impresiones digitales o lectores de códigos de barras, que han simplificado el acceso de todos a los múltiples campos de la organización comunitaria.

Este mismo sistema político de administración se ocupa de dotar de cierta significación al aparato escolar, y a la vez, eficientizar las posibilidades de la burocracia para que todos los sujetos, aunque estén mínimamente alfabetizados, puedan insertarse socialmente y ejercer sus derechos ciudadanos a la educación, la salud, la vivienda, la seguridad, el salario, etcétera.

Se podría afirmar entonces que la cultura de la imagen y de la «máquina tecnológica», es eficaz, tanto más incluso que la cultura de la lectoescritura, que para su desarrollo individual necesita de un tiempo prolongado y de ciertas condiciones. Sin embargo, estas formas que adopta el sistema para una administración exitosa mediante el diseño y la producción de imágenes, no necesariamente estimulan en los individuos su capacidad de multiplicar sentidos, de resignificar, de inventar universos propios y crear mundos imaginarios. Esas posibilidades subjetivas siguen vinculadas al capital cultural, que coincide con una base material que lo sustenta.

Dentro de las posibilidades expresivas de la comunicación visual y auditiva, los cómics ofrecen ciertas complejidades pedagógicas. Conviene aclarar que, desde nuestra óptica, la Pedagogía no es didáctica ni teoría prescriptiva, sino que debe considerarse como una ciencia que reclama la apertura a otros saberes como la sociología, la política, la semiología, las ciencias de la comunicación o la filosofía.

En este sentido, el mito de Superman encarnando al héroe americano que anima la lucha del bien contra el mal más allá de lo político, sigue siendo un ícono del mercado que en sus distintas versiones de historieta, animación o cine, aún genera millones de ganancias para las empresas productoras, expresado esto sólo a modo de ejemplo.

Frente a las limitaciones de un arte consumido por las variables capitalistas, emergen expresiones alternativas muy interesantes. Por citar sólo algunas, la obra sobre el fenómeno del nazismo de Art Spiegelman o el trabajo de Winshluss en «Mundo Mérroll», burlándose de Disney, 
son manifestaciones muy estimulantes.

En Argentina, hay un movimiento de autores jóvenes que relatan, desde el género de la historieta, crudas autobiografías, descubrimientos existenciales o reflexiones sobre la identidad sexual, como lo señala el libro Informe. Historieta argentina del siglo XXI, publicado en 2015 por la Editorial Municipal de Rosario, que compila estilos narrativos de veinte artistas de menos de cuarenta años.

Mientras tanto, el clima especial que se gestó durante estas Jornadas en la FADU-UNL, da cuenta de la originalidad de la propuesta que ya se plantea desde el Seminario Tamayo, y que se abre a otras experiencias en el campo de la comunicación visual y sonora, tanto académicas como profesionales, incorporando lenguajes alternativos y tecnologías aplicadas a la difusión de contenidos educativos y culturales, como la instalación de la señal digital que ha transmitido en vivo esta experiencia por internet, a través del canal de You Tube tetetv.

Con un espíritu extencionista, estas Jornadas lograron abrir un espacio académico e investigativo con una dinámica original de encuentros que giraron en torno de las problemáticas del diseño, la conceptualización y las perspectivas actuales del cómic expandido y emergente. Para analizar estos relatos en su forma, contenido y dispositivos tecnológicos un grupo de profesionales y académicos, así como numerosos artistas, becarios y estudiantes, participaron en talleres y ponencias que abordaron la creación de figuras recortadas, juguetes ópticos, software innovadores, teatro filmado, fanzines, vidding y cómics pastiches que, en palabras de los organizadores, tejieron una auténtica red de creación compartida.

\section{Referencias bibliográficas}

- ABENSOUR, M. et al. (2005). Voces de la filosofía francesa contemporánea. Buenos Aires: Colihue.

- APPLE, M. (1997). Teoría crítica y educación. Trad. Soledad Laclaud. Buenos Aires: Miño y Dávila Editores.

- COSTA, M. C. (2007). Teoría estético-crítica de la educación. Santa Fe: CEEC.

- DEBRAY, R. (1992). Vie et mort de l'image. Paris: Gallimard.

- ECO, U. (2012). Apocalípticos e integrados. Trad. Andrés Blogar.

Buenos Aires: Delbolsillo.

- TAMAYO, Y. (2014). Flexibilidad curricular en la educación superior. Una experiencia desde Argentina. Espacio diseño, (224), 42-47. México: Universidad Autónoma Metropolitana. 